\title{
EL FENÓMENO INTERTEXTUAL Nociones sobre terminología aplicada a los álbumes ilustrados
}

Resumo: En este artículo se expone la relevancia del álbum ilustrado como lugar de comunicación entre en el lectorespectador y el autor/es (literario y/o plástico; en adelante "autor") del libro. El punto de vista enmarca y se centra en la relevancia de la imagen, puesto que quien lo escribe se vincula al área visual; sin embargo, se parte de la premisa de que el autor realiza una propuesta de comunicación total (Literaria y Plástica) a través de las páginas. Se citan específicamente álbumes que contienen referentes culturales en las ilustraciones y se indica terminología novedosa y específica. También se exponen las formas de inserción de los referentes culturales, las finalidades, etc. Los álbumes citados están producidos por autores consagrados en literatura infantil y suponen un repertorio para tener en cuenta con respecto a la difusión de la cultura visual.

Palabras clave: Literatura infantil, álbumes ilustrados, ilustración, referentes culturales, intertextualidad, cultura visual.

\section{THE INTERTEXTUAL PHENOMENON Notions of terminology applied to illustrated albums}

\begin{abstract}
This article exposes the relevance of the picturebook as a place of communication between the readerviewer and the author/s of the book (literary and/or plastic, hereinafter "author") is exposed. The point of view frames and focuses on the relevance of the image, since who writes is linked to the area visual; however, it is based on the premise that the author makes a total communication proposal (Literary and Visual-Plastic) through the pages. Specific picture books are cited that contain cultural references in the illustrations and new and specific terminology is indicated. The forms of insertion of the cultural references, the purposes, etc. are also exposed. The cited picture books are produced by famous authors in children's literature and represent a repertoire to take into account with regard to the spread visual culture
\end{abstract}

Keywords: Children's literature, picturebooks, illustration, cultural references, intertextuality, visual culture.

\footnotetext{
${ }^{1}$ Profesora Universitaria - CEU Cardenal Spínola - Fundación San Pablo Andalucía CEU, Sevilla (España)

Licenciada en Bellas Artes y Doctora en Ciencias de la Educación por la Universidad de Sevilla (mjlobato@ ceuandalucia.es)
} 


\section{Las manifestaciones intertextuales}

El camino y estudio interdisciplinar de las relaciones o "comparación interartística" demuestra la existencia de analogías formales que revelan homologías estructurales entre textos e imágenes, y traza comparaciones específicas entre las artes visuales y verbales con la poética y la retórica (Mitchell, 2009, p. 80). A nivel internacional y en origen, el concepto de intertextualidad es introducido por Bakhtine y difundido por G. Genette (1989, p. 10) y J. Kristeva (1967, pp. 440-441) y se basa en el análisis de la copresencia de textos o evocación de hipotextos. En el panorama español, los estudios de Mendoza Fillola (2000, p. 14) son decisivos para definir y concretar la idea y terminología que nos ocupa. El autor realiza una concisa aproximación a las pasarelas entre la Literatura y las Artes visuales.

Genette definió el término Intertextualidad como la presencia real de un texto en otro (a través de citas, plagio, alusión). Nos referimos a la presencia de un texto como imagen, ilustración, icono que trasciende en relación explícita o implícita, manifiesta o secreta, con otra manifestación de lo visual.

El fenómeno intertextual, como relación entre dos textos, uno literario y otro visual, ha estado presente en toda la historia de la literatura y de las artes. En la reiterada citación de temas, tópicos, formas, macroestructuras textuales, recursos estilísticos, etc., además de las alusiones, citas, imitaciones, influencias, etc. se manifiesta el hecho intertextual (2003, p. 27). Los términos aplicados a las artes y la cultura visuales se han acuñado a la luz de las denominaciones de la Literatura.

El álbum ilustrado como artefacto artístico, es una forma clásica, pero a la vez novedosa de estructura multimodal que reúne los códigos visual-plástico y verbal. En él, la composición espacial y la dimensión temporal del ritmo narrativo abren las puertas a un discurso polifónico que ofrece múltiples posibilidades para despertar los intereses de niños y adolescentes por el fenómeno intertextual. Las voces creadas, imágenes y palabras, se caracterizan por sus específicas relaciones, que no siempre van en paralelo, ya que pueden corroborarse, reafirmarse; pero también contradecirse o ponerse en duda.

En este artículo se van a considerar solo publicaciones y álbumes que, como valor añadido, contienen referentes culturales. El ilustrador pone en marcha la apropiación interpretativa de la imagen, tanto del texto como de la imagen. El libro, por lo tanto, se convierte en un lugar de complicidad con el espectador; pero la recepción puede variar en cada persona, ya que pueden acuñar diversos niveles de lectura interpretativa. Por eso se corre el peligro de que quienes se enfrentan al álbum ilustrado pueden no poseer la capacidad requerida, no ya para comprenderlo; sino para disfrutarlo.

Según sea su espectador del álbum, niño, joven o adulto y su competencia cultural, también su acercamiento al discurso podrá variar. No podemos olvidarnos del nivel de sofisticación de la inserción del referente cultural. Lo deseable sería que el encuentro con el álbum pueda llevar al lector a investigar señales, formular hipótesis y experimentar con sus posibles significados, ser un aliciente, un acicate que impulse a la reflexión sobre el papel de la imagen y los referentes que incluye. El libro puede, incluso; y esto es lo que más nos entusiasma, incitar a la búsqueda y reconocimiento de referentes culturales para reconocer sus valores simbólicos.

\section{Concretando las denominaciones}

Para abordar y enmarcar la cuestión de este artículo necesitamos concretar algunas ideas y términos que se han acotado en estudios previos (Hoster, Lobato, Ruiz, 2017, pp.165-184), pero que resultan ser novedosos porque se crean por la necesidad de acuñar relaciones formales entre imágenes y principalmente en el álbum ilustrado. 
En los párrafos anteriores hemos determinado que al referirnos a texto, lo hacemos tanto si se trata de un texto musical, como visual-plástico o literario. Se cita como ejemplo una obra de arte, sin descartar otros referentes culturales: el hipotexto será el origen, por ejemplo La caída de los ángeles rebeldes; el hipertexto será el resultado referido a su presencia reelaborada en la canción. El caso del video de BTS responde a la idea de mosaico de citas de hipotextos (Kristeva, 1967).

En unas primeras acepciones, como las más novedosas, si nos centrarnos solo en el plano de lo visual y en las relaciones que los textos pictóricos (y visuales) pueden establecer entre sí, se definen como interpictorialidad, intervisualidad.

- Interpictorialidad cuando la imagen pictórica está presente en el texto como una cita explícita, una forma de plagio, una alusión, o incluso en su forma icónica (Louvel, 2011, pp.56-57)

- Intervisualidad cuando imágenes aluden a otras imágenes de forma genérica (Hoster, Lobato, Ruiz, 2017).

Amo Sánchez-Fortún (2005, pp.75-77) advertía sobre la gran cantidad de terminología específica para referirse a todo lo que pone un texto en relación, manifiesta o secreta, con otros textos y establece cinco tipos de conexiones posibles:

- Hipertextualidad: relación que mantiene un texto imitador (hipertexto) y el texto imitado (hipotexto), a través de parodia o el travestimiento.

- Architextualidad: durante la comunicación literaria, el lector ha de poner en marcha su competencia textual [...], así como lanzar predicciones, establecer hipótesis y construir provisionalmente el sentido del texto. [...] toda obra literaria supone un horizonte de expectativas, es decir un conjunto de reglas preexistentes para orientar la comprensión del lector y permitirle una recepción apreciativa.

- Metatextualidad: el comentario -normalmente crítico- que un texto hace de otro.

- Paratextualidad: la relación del texto con su paratexto, [...] conjunto de signos que presentan al texto (título, subtítulo, prefacio, [...])

- Intertextualidad: presencia [...] de un texto en otro, mediante citas, plagios o alusiones; o [...] referencia a otros libros, citando personajes, imitando formas de escribir, situaciones, diálogos.

- Intratextualidad, cuando "el texto y las ilustraciones se refieren todo el tiempo a sí mismos, y esto genera nuevas lecturas y recorridos por las páginas hacia delante y hacia atrás, y búsqueda entre las palabras y las imágenes para hacer todavía más conexiones entre los nuevos mensajes visuales" (Arizpe y Styles, 2004, p.159).

\section{Álbumes homenaje}

Se pretende determinar, por tanto, qué presencia en una publicación resulta ser intertextual. No todas aquellas publicaciones que contienen referencias a artistas, obras de arte $\mathrm{u}$ otras citaciones cultas son álbumes intertextuales.

En un primer apartado podríamos encontrar a artistas que son recogidos por el autor en una publicación explícita. El homenaje queda patente ya en el título de la obra. No se trata de una cita intertextual en sí misma, pero el tratamiento de la imagen va más allá de las referencias a las creaciones del artista homenajeado. Las ilustraciones adoptan su estilo.

Bimba Landmann en Un niño llamado Giotto (2003) imita el lenguaje visual de Giotto di Bondone. Con intención de adquirir una similitud en el estilo, se percibe acercamiento en tonalidades y 
composición plástica. Se reconoce el estilo del artista en las evocaciones de la Basílica de San Francisco de Asís. Giotto realiza también una franja inferior de pequeñas escenas. Landmann imita las estructuras arquitectónicas y los dorados de contorno en las viñetas inferiores.

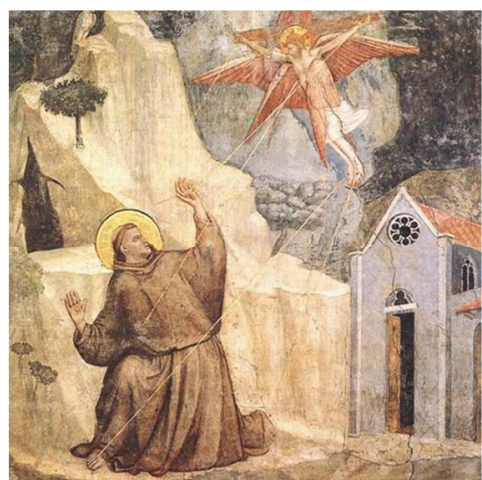

Figura 01

Di Bondone, G.: San Francisco recibe los estigmas, ca. 1295

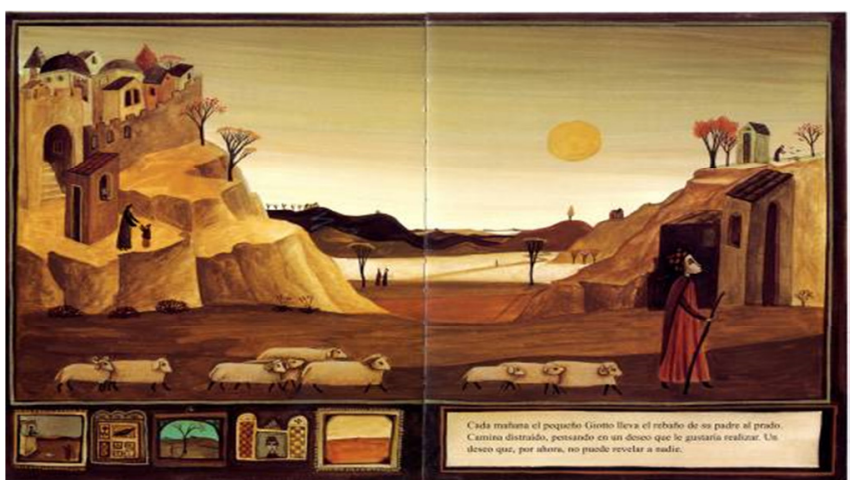

Figura 02

Guarnieri, P., Landmann, B. (Il.) Un niño llamado Giotto. Barcelona: Tuscania Editorial, 2003

En Cómo me convertí en Marc Chagall (2012); sin embargo, Landmann realiza las ilustraciones con técnica diferenciada. Se trata de maquetas que se fotografían para dar lugar a la ilustración. Las maquetas recogen paisajes de las composiciones en las que podemos ver objetos y elementos representativos del autor. Evoca también a través de gamas de colores del artista, atrevidos y fortísimos: rojo magenta, violeta, azul...colores que nos trasladan al universo onírico de Chagall. En las ilustraciones de Landmann se mezclan imágenes de la primera etapa de Chagall como pintor, en Vitebsk, su ciudad natal en Bielorrusia, e imágenes de sus estancias en San Petersburgo (Rusia) París (Francia), etc. Este álbum, como homenaje al pintor, recoge imágenes religiosas cercanas a iconos bizantinos, ángeles, candelabros de siete brazos, músicos, rabinos y la sempiterna cabra, elementos de la referencia a las obras de Chagall.

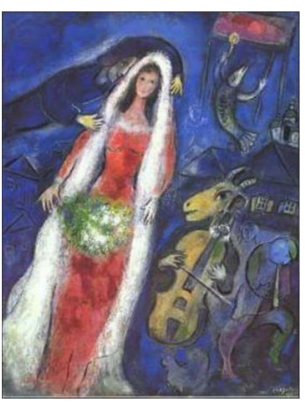

Figura 03

Chagall, M. La novia, 1950

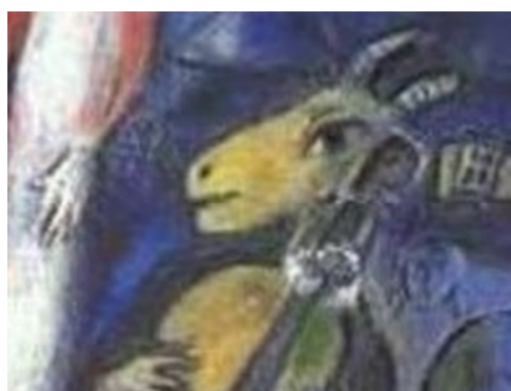

Figura 04

Chagall, M. La novia, (detalle) 1950

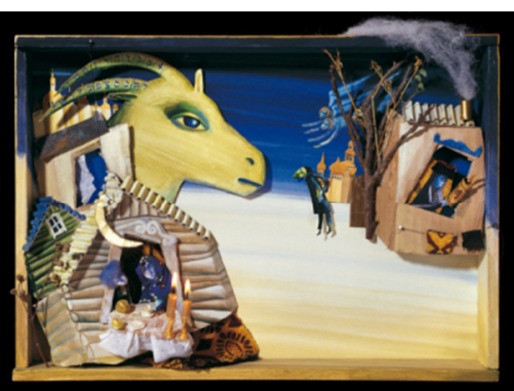

Figura 05

Landmann, B. Cómo me convertí en Marc Chagall, 2012

\section{Álbumes con apropiaciones y reelaboraciones de referentes culturales}

Cuando en un álbum se inserta un referente cultural de una forma no explícita se producen reelaboraciones intertextuales que intervienen de forma significativa en la narración. Comenzamos con 
denominaciones acuñadas en un primer acercamiento básico, para luego profundizar en al modus operandi (Hoster y Lobato, 2012).

La revisión de investigaciones previas se inicia en Valleau (2006), se amplía la tipología de Bruel (cfr. Hoster y Lobato, 2011, p.114-116), y se participa también de las opiniones de Beckett (2001).

Valleau aporta un análisis referido al grado de fidelidad formal, con respecto al referente cultural o imagen de origen, y clasifica básicamente en calco, copia y evocación. Sin embargo, el sistema de referencias intertextextuales podrían contener criterios más complejos (Hoster y Lobato, 2012); ya que se basa en procesos duales que se dividen en:

- Amplitud del hipotexto: se refiere al lugar y extensión que ocupa el referente reelaborado en la ilustración. Puede rescatar la obra original completa, la base compositiva de esta; o bien limitarse a deconstruir un elemento de aquella, descontextualizándolo.

- Procedimientos para el rescate del hipotexto: el calco (constructivo), la copia, o la evocación (deconstructivo).

La presencia de los referentes en las ilustraciones posibilita que el lector realice contribuciones a la construcción de significado. Resulta de vital importancia la identificación de componentes intertextuales y conexiones que permiten reconstruir informaciones. Con respecto a la función del hipotexto en el proceso de construcción de la ilustración resultante, dicho hipotexto podría utilizarse como:

- Base compositiva de la nueva ilustración.

- Un elemento más de la composición resultante.

Por otro lado, toma importancia la trascendencia y significatividad que el referente cultural asume en el álbum ilustrado. Es necesario reconocer la función o faceta que puede desempeñar en la imagen o ilustración en que se inserta. En otros estudios (Lobato y Hoster, 2011 y 2014; y Lobato, 2013) se realiza una aproximación en la que se analiza la presencia de diferentes de obras de arte 0 artistas cuya cita contiene una función intertextual significativa. Podemos encontrarnos con álbumes de faceta conservadora; en la que se realiza un rescate de los valores culturales consagrados y se aprecia un homenaje a la cultura consensuada y consagrada (Colomer, 2006, p. 48). En este caso, el álbum es usado como instrumento de enaltecimiento cultural, y el ilustrador asume función de historiador del arte y difusor de cultura. Por otro lado, la faceta subversiva, revisa aspectos críticos, cuestiona relaciones personales, de familia y emocionales en la sociedad actual, otras épocas o hechos históricos, etc. Son aquellos referentes que resultan significativos y decisivos para comprender la narración. La interpretación de aspectos no explícitos y simbólicos del discurso descubre pistas sutiles a través de las que se aprecia críticas o denuncias, que desatan el lado más ácido e irónico. Esta idea se contrapone al álbum como género que toca temas de forma superficial.

Presentamos una selección de ejemplos:

El libro Emigrantes de Shaun Tan, representa el calco en su faceta crítica. Inspirado en historias de vida reales, hace clara alusión, sobre todo, a la llegada de europeos a principios del s. XX a los Estados Unidos. Las ilustraciones, recogen la lucha por la supervivencia en un mundo de otras formas de vida y costumbres ajenas; pero en el que se puede encontrar ayuda.

El autor construye una compleja estructura de narración discontinua. Mediante el uso exclusivo de imágenes de tono sepia, que dan uniformidad a la trama, se enlazan o intercalan tres historias.Una de las 
imágenes podría estar basada en una pintura de Tom Roberts; otras podrían corresponderse con fotografías de la época. El hipotexto es base de la composición completa.

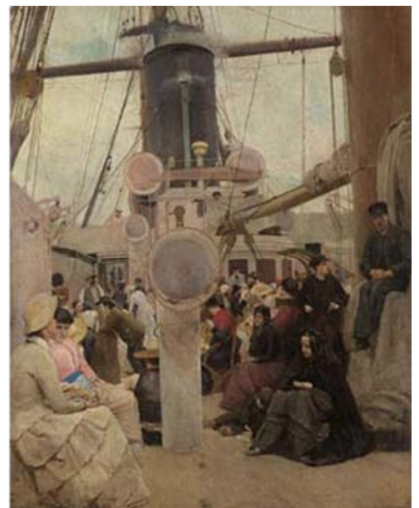

Figura 06

Roberts, T. Coming Sout, ca.1886 (imagen en versión simétrica)

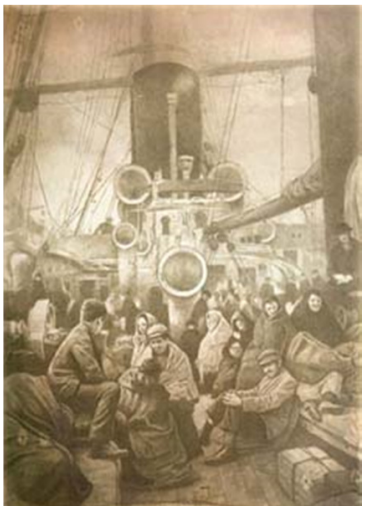

Figura 07

Tan, S. Emigrantes, 2006

Podemos apreciar localizaciones como Nueva York, Venecia o Bari. En este caso es relevante la cita de los lugares, porque son significativos para la historia.

El álbum de Browne Voces en el parque presenta un fragmento y lo usa como composición. Aunque en esencia se trata de un álbum crítico, el hipotexto representa el calco en su faceta conservadora, porque la presencia del referente no propone una lectura que ponga en tela de juicio la actuación de los personajes. El rescate es un claro homenaje y rescate propiciado por Browne (Lobato y Hoster, 2014).

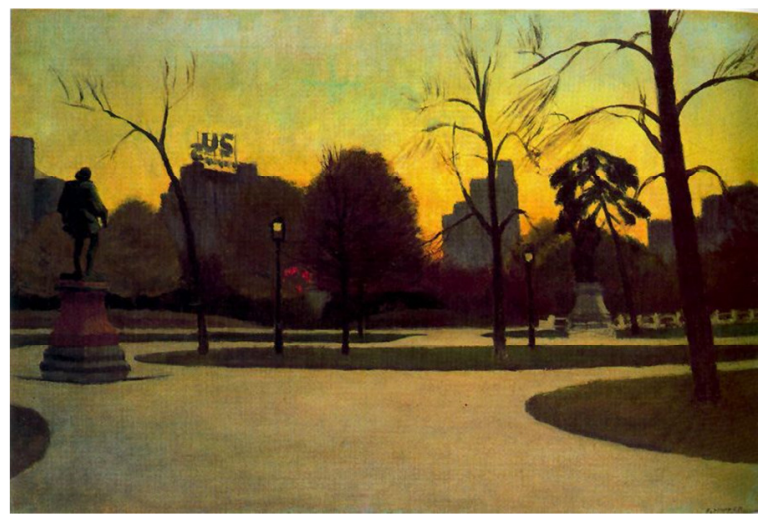

Figura 08

Hopper E. Monumento a Shakespeare al atardecer, 1935

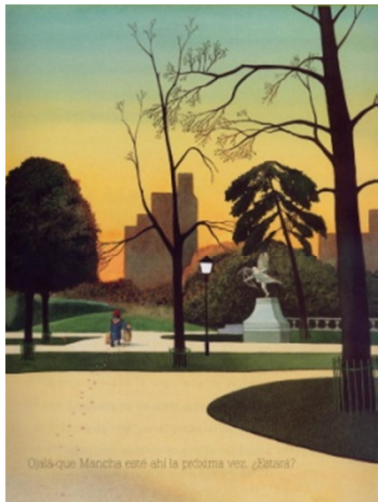

Figura 09

Los elementos en La flor más grande del mundo, con texto de José Saramago, representan la copia que hace reflexionar. João Caetano explica: "estos elementos...refuerzan ideas del libro: una viaje de un niño persiguiendo una causa, un himno a la libertad y al altruismo, un ejemplo de universalidad y de humanismo". Este álbum establece una interesante transgresión visual y espacio-temporal en la que un niño encara un viaje y asume una ingente aventura, debatiéndose entre lo real y el escepticismo. 
El ilustrador inserta textos visuales ajenos de forma esporádica. Algunas veces se trata de imágenes originales de obras de arte diferenciadas a través de la técnica. (Véase $O$ Traxe novo do rei, 2016.) No sacrifica su propio estilo y sello personal, solo añade elementos aislados en forma de recortes que se superponen al diseño perdiendo su uso en origen para adoptar uno novedoso. Caetano reclama la complicidad para desvelar la doble función (Lobato 2013).

En este caso, el álbum hace referencia a una obra de procedencia exótica, un detalle de un biombo japones atribuido a Kano Domi de la Escuela Kano, que representa la presencia de portugueses en los siglos XVI y XVII en Japón. Se trata de un fragmento usado también como elemento de la composición.

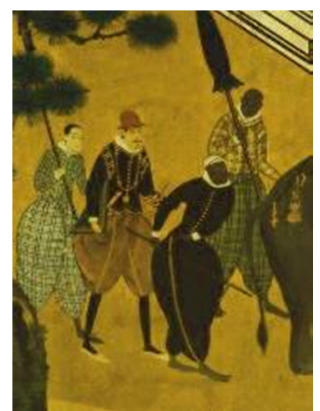

Figura 10

Arte Namban Japonés, (panel de Kano Domi de la Escuela de Kano), 1593-1600

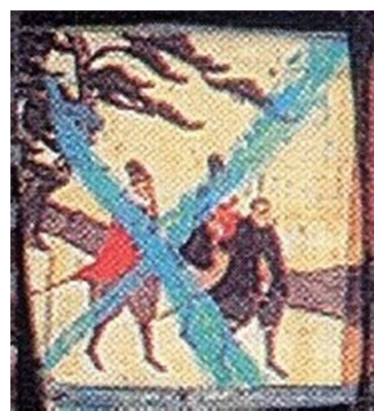

Figura 11

Saramago, J., Caetano, J. (il.) La flor más grande del mundo (detalle), 2001

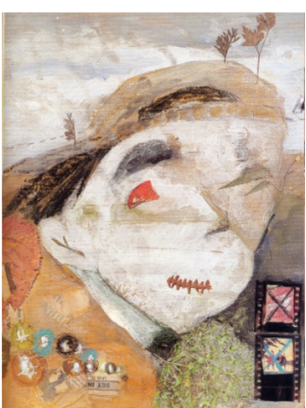

Figura 12

Saramago, J., Caetano, J. (il.) $L a$ flor más grande del mundo, 2001

La copia en su faceta conservadora viene de la mano de la autora Rocío Martínez, con la publicación Mi princesa Himilce, siempre tuyo Aníbal (2016). Las ilustraciones recogen datos históricos sobre las campañas militares de Aníbal Barca, general cartaginés y personaje decisivo en el devenir de la península ibérica, Hispania, frente a colosal Imperio Romano. En el texto se dan cita términos que ayudan a conocer datos bélicos (Batallas de Trebia, Tesino o Trasimeno o la Victoria en Cannas); situaciones geográficas (Cartago Nova y Gadir); o términos específicos y propios de la época; (ejército de elefantes de Anibal, équites o caballeros romanos, la falcada o espada de acero originaria de Iberia, etc.). Según palabras de la autora, las ilustraciones contienen un valor añadido porque "la principal fuente gráfica para ilustrar el libro ha sido la cerámica íbera, sobre todo la del estilo de Elche y Archena". Aunque todo el álbum se realiza a imitación del estilo, podemos detectar elementos específicos, usados también como elementos de la composición.

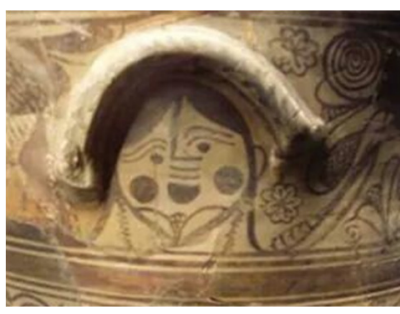

Figura 13

Cerámica ibérica de estilo Elche o Archena (detalle)

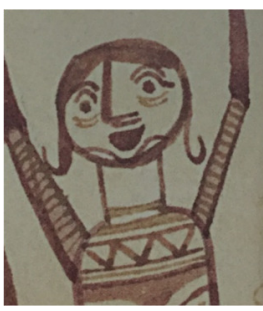

Figura 14

Martínez, R. Mi princesa Himilce... (detalle), 2016

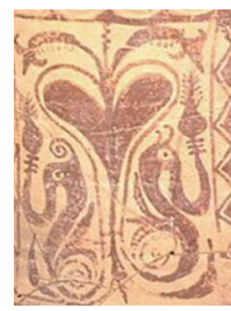

Figura 15

Cerámica ibérica de estilo Elche o Archena (detalle)

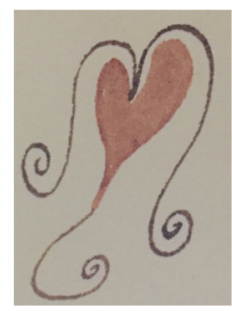

Figura 16

Martínez, R. Mi princesa Himilce...(detalle), 2016 
La muestra del álbum Fernando Furioso (2004) de Satoshi Kitamura podríamos calificarla de evocación. La composición tiene cierta similitud con la estructura original. En las imágenes un niño descarga una rabieta. El título nos traslada a Orlando Furioso (1532) de Ludovico Ariosto, poema épico con el que se relaciona por la trama compleja de locura de su personaje, relaciones imposibles, guerras y hechos delirantes. Parece que la intertextualidad es evidente; pero va más allá, y en otro sentido: el álbum revela en las ilustraciones obras de Gustavo Doré (1879).

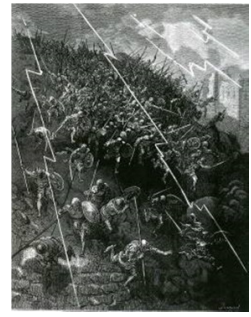

Figura 17

Ariosto y Doré, G. (ilust.): Orlando furioso (1879)

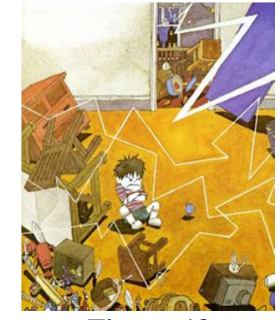

Figura 18

Oram, H. y Kitamura, $S$.

Fernando furioso, 2004

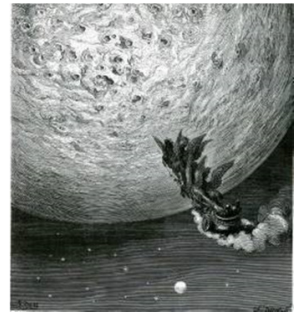

Figura 19

Ariosto y Doré, G. (ilust.): Orlando furioso, 1879

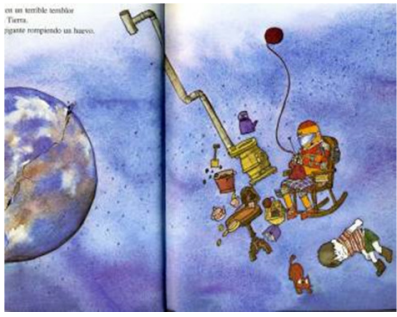

Figura 20

Oram, H. y Kitamura, S. Fernando furioso, 2004

En las imágenes de Kitamura cobra sentido la desmesurada reacción del niño cuando se conoce la presencia y reelaboración del Orlando Furioso de Ariosto.

Las creaciones de la pareja formada por Andrej Dugin y Olga Dugina, aportan una evocación conservadora. En este caso la amplitud del hipotexto evocado se aplica a toda la ilustración. Siendo fieles a su propio estilo, trasladan la ambientación sin concurrencia de elementos concretos copiados, pero el espectador percibe la factura pictórica. Se evocan pasajes que remiten principalmente a El Bosco y Bruegel el Viejo, cuya presencia en mezcolanza, da lugar a imágenes de naturaleza artificiosa. En un breve repaso se evidencia la presencia de referencias en Las plumas del Dragón y El Sastrecillo Valiente. El primero de ellos es adaptación de un cuento de múltiples variantes a en literatura infantil. La popular narración trata de un viaje de ida y vuelta al infierno de un sobrevenido héroe, en la que se mezclan reminiscencias iconográficas laicas, religiosas y mitológicas. Henry, el hijo de un leñador, debe enriquecerse y realizar tres pruebas de valor para poder casarse con la hija de un adinerado posadero. Las referencias se instalan en personajes, arquitecturas y paisajes; objetos; animales mecánicos o antropomórficos y escatológicos; y en los monogramas o letras como firmas de autores. Véanse, por ejemplo, los landsknecht (soldado mercenario) del renacimiento germano de Durero.

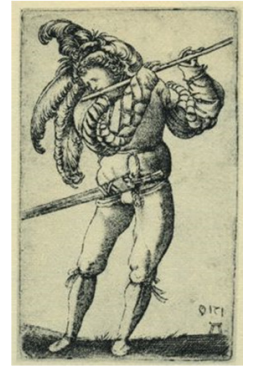

Figura 21

Durero, A.: Maravilloso ropaje, 1510 (imagen invertida)

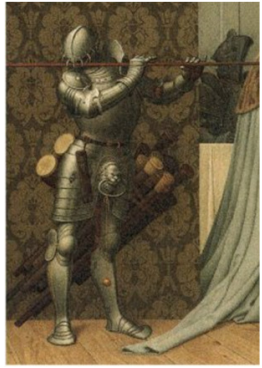

Figura 22

Dugina, O. y Dugin, A. The Brave Little Tailor, 2000, detalle

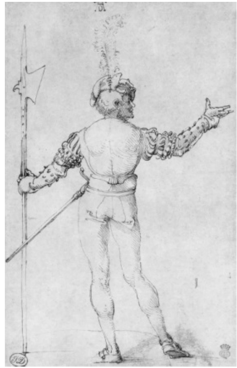

Figura 23

Durero, A.: Soldado mercenario, ca. 1504

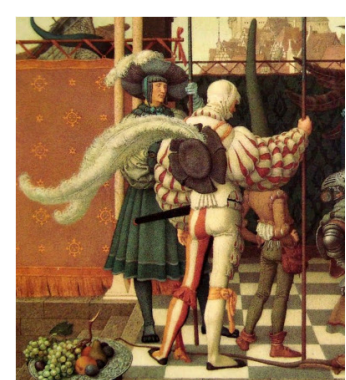

Figura 24

Dugina, O. y Dugin, A. The Brave Little Tailor, 2000, detalle 
Otros guiños evidencian el expreso deseo de aludir a pintores determinados: cuando Henry está parado frente a la granja, la ilustración es profusa en lettering y símbolos, incluyendo monogramas de artistas. Es muy fácil apreciar las letras " $A D$ " invertidas sobre la roca, monograma de Durero.

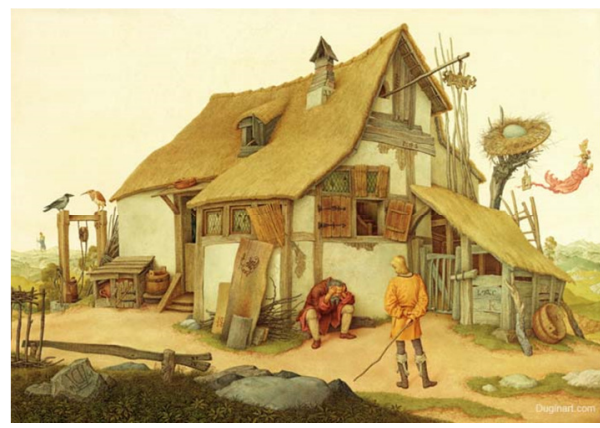

Figura 25

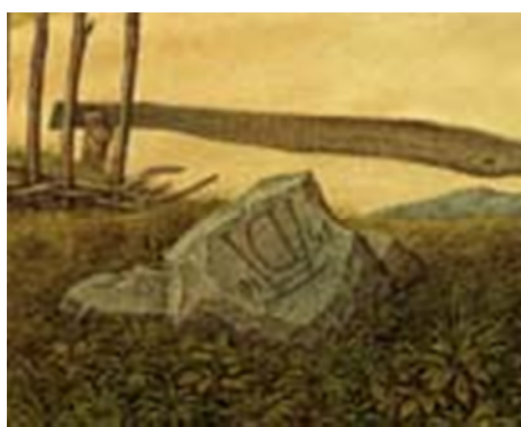

Figura 26

Dugina, O. y Dugin, A. Las plumas del Dragón, 2014 Dugina, O. y Dugin, A. Las plumas del Dragón, 2014

\section{Cuadro resumen del modus operandi en la reelaboración de referentes culturales}

Como compendio del análisis en que los referentes culturales se reelaboran para insertarse en las ilustraciones, aportamos una síntesis final (Hoster y Lobato, 2012, p. 78).

\begin{tabular}{|c|c|c|c|}
\hline \multicolumn{3}{|c|}{ Amplitud del hipotexto } \\
\hline \multicolumn{3}{|c|}{ Modo de inserción del hipotexto en la ilustración } \\
\hline $\begin{array}{c}\text { Base compositiva en la } \\
\text { ilustración completa }\end{array}$ & $\begin{array}{c}\text { Elemento de la } \\
\text { composición }\end{array}$ & $\begin{array}{c}\text { Base compositiva en la } \\
\text { ilustración completa }\end{array}$ & $\begin{array}{c}\text { Elemento de la } \\
\text { composición }\end{array}$ \\
\hline \multicolumn{3}{|c|}{ Función/faceta del hipotexto en la ilustración } \\
\hline \multicolumn{3}{|c|}{ Faceta conservadora } & Faceta subversiva o crítica \\
\hline
\end{tabular}

\section{Encuentros provocados y acompañamiento en cultura visual}

Se ha podido comprobar cómo concurren en los álbumes citas de cuadros, grabados, fotografías o novelas. El objetivo consiste en la ampliación del intertexto de los alumnos/as con una invitación a la identificación y posterior contextualización significativa de los mismos de los referentes, se pone en evidencia la falta de competencia, sin formación previa (Lobato y Hoster, 2012). La presencia de referentes culturales reelaborados hace imprescindible el acompañamiento para que puedan ser interpretadas en plenitud. No cabe un manejo del libro de manera autónoma.

Una vez clarificada las denominaciones y reconocidos los referentes tampoco está garantizada su comprensión en el contexto del álbum. Sin embargo, el hecho de empezar a entrar en complicidad con el autor, despejando algunos de las incógnitas, se espera que empuje a continuar la búsqueda y realizar 
hipótesis sobre la aportación del referente al sentido del álbum y que la experiencia mejore la valoración y el grado de satisfacción que el espectador tiene de este sector de la Literatura. Se entiende como decisiva la figura de acompañamiento que alienta e involucra al estudiante sigue siendo decisiva.

\section{Conclusiones}

En la era digital son todavía muchos los recursos no digitales que sirven para estimular el puro placer de jugar a encontrar y desenmascarar el significado de un referente cultural. Sin embargo, resulta igual importante que el apropiarse de una narración se haga desde un punto de vista que resulte significativo y sea relevante para formar en la competencia artística.

Como lectores/espectadores competentes encontramos un inmenso gozo en el reconocimiento de los referentes. Se aprecia el intrínseco valor y trascendencia de la aportación intertextual, y las historias en el álbum se hacen más significativas, pero podemos encontrar variados discursos en las aportaciones de los hipotextos; que no siempre son captados por todo el público.

Focalizamos la atención en el desconocimiento que del hipotexto suelen tener niños, jóvenes, y adultos también. La problemática radicada, además, en la ausencia de criterio para la detección y clasificación del modo en que las fuentes hipotextuales se insertan en la ilustración.

En estas circunstancias, se ha realizado una revisión de la terminología actualizada y aspectos importantes para el reconocimiento de los referentes culturales: su posible extensión (amplitud); su modo de inserción (como base de la composición o como elemento); así como sus funciones/facetas (conservadora y subversiva o crítica).

\section{Referencias bibliográficas}

Amo Sánchez-Fortún, J. (2005). El papel del álbum en el desarrollo del intertexto lector. En Campo Abierto, Revista de Educación, $n^{\circ} 28$.

Arizpe, E. y Styles, M. (2004). Lectura de imágenes. Los niños interpretan textos visuales. México: Fondo de Cultura Económica.

Ballesteros, X. y Caetano, J. (Il.) (2011). Il vestito nuovo del re. Pontevedra: Kalandraka.

Beckett, S. (2001). Parodic play with paintings in picture books. Children's Literature. Baltimore: The Johns Hopkins University Press, vol. 29.

Browne, A. (1999). Voces en el parque, México: Fondo de Cultura Económica.

Bruel, Ch. (2001). Anthony Browne. París: Éditions Être, Collection Boîtazoutils.

Colomer, T. (2006). La protección de buenas noches, luna y otros valores actuales. Peonza, no 75-76.

Dugina, O., Dugin, A. y Esterl, A. (2014). Las plumas del dragón. México: Fondo de Cultura Económica.

Esterl, A., Dugina, O. y Dugin, A., (2001). El sastrecillo valiente. México: Fondo de Cultura Económica.

Genette, G. y Fernández Prieto, C. (Trad.) (1989). Palimpsestos. La literatura en segundo grado. Madrid: Taurus.

Guarnieri, P. y Landmann, B. (Il.) (2003). Un niño llamado Giotto. Barcelona: Tuscania Editorial.

Hoster, B. y Lobato, $\mathrm{M}^{\mathrm{a}} \mathrm{J}$. (2012). Modus operandi en el entramado intertextual de la obra de Anthony Browne. EA Revista de investigación Educativa Escuela Abierta, $n^{\circ}$ 15. Sevilla: Servicio de Publicaciones de la Fundación San Pablo Andalucía CEU. 
Hoster, B., Lobato, M. J. and Ruiz, A. M. (2017). Interpictoriality in picturebooks. En B. Kummerling-Meibauer (Coord.), The Routledge Companion to Picturebooks. New York: Ed. Routledge.

Landmann, B. (2005). Come sono diventato Marc Chagall. Milano: Edizioni Arka.

Kristeva, J. (1967). Bakhtine, le mot, le dialogue et le roman. Critique, nº 239, pp. 440-441.

Landmann, B. (2012). Cómo me convertí en Marc Chagall. Madrid: Editorial Laberinto.

Lobato, $M^{a}$ J. (2013). Intertestualità e intericonicità. Una valida risorsa per il giovane lettore. En M. Campagnaro, Incanto e racconto nel labirinto delle figure. Trento (Italia): Ed. Erickson.

Lobato, M $\mathrm{M}^{\mathrm{a}}$ J. (2016). Simbología y retórica en la obra de Anthony Browne: implicaciones y aplicaciones para la enseñanza de la cultura visual. (Tesis no publicada). Universidad de Sevilla: Facultad de Ciencias de la Educación.

Lobato, Mª J. and Hoster, B. (2014). An Approximation to Intertextuality in Picturebooks: Anthony Browne and his Hipotexts. En B. Kummerling-Meibauer (Coord.), Picturebooks. Representation and Narration. New York: Ed. Routledge.

Lobato, M ${ }^{\mathrm{a}}$ J. y Hoster, B. (2017). Ampliación del intertexto de los estudiantes de Magisterio a través de la obra de Anthony Browne. En González, Monleón y González (Eds.), Ilustrando identidades. Arte, ilustración y cultura visual en Educación Infantil y Primaria. Barcelona: Ediciones Octaedro y Universidad de Granada pp. 141-148.

Louvel, L. (2011). Poetics of the Iconotext, Surrey: Ashgate Publishing, Ltd.

Martínez, R. (2016). Mi princesa Himilce, siempre tuyo Aníbal. Barcelona: Thule ediciones.

Mendoza Fillola, A. (Coord.) (2000). Lecturas de museo: orientaciones sobre la recepción de relaciones entre la literatura y las artes. Barcelona: Universidad de Barcelona.

Mendoza Fillola, A. (2003). Los intertextos: del discurso a la recepción. En A. Mendoza Fillola y P. Cerrillo Torremocha. En Intertextos: aspectos sobre la recepción del discurso artístico. Cuenca: Ediciones de la Universidad de Castilla-La Mancha.

Mitchell, W. J. T. (2009). Teoría de la imagen. Madrid: AKAL/Estudios Visuales.

Oram, H. y Kitamura, S. (2004). Fernando furioso. Venezuela: Ekaré.

Saramago, J., Caetano, J. (Il.) (2001). La flor más grande del mundo, Madrid: Alfaguara.

Schritter, I. (2005). La otra lectura. Las ilustraciones en los libros para niños. Buenos Aires: Lugar Editorial/Universidad Nacional del Litoral.

Tan, S. (2007). Emigrantes. Granada: Barbara Fiore.

\section{Otras referencias}

Imaginaria (2010). Revista quincenal sobre literatura infantil y juvenil, $n^{\circ} 282$. http://www.imaginaria.com.ar/2010/11/emigrantes/

Hoster, B. y Lobato, $\mathrm{M}^{\mathrm{a}} \mathrm{J}$. (2011). Acercamiento al imaginario de Browne: los referentes culturales en la ilustración. En EARI - Educación Artística Revista de Educación, 2, 113-117.

http://issuu.com/eari/docs/revista_eari_numero_2_2011_web y http://artemaestrosymuseos.wordpress.com.

Valleau, G. (2006). Degas and Seurat and Magritte! Oh My! Classical Art in Picturebooks. En The Looking Glass: New Perspectives on Children's Literature, $n^{\circ} 3$, vol. 10. Disponible en http://www.lib.latrobe.edu.au/ojs/index.php/tlg/issue/view/7 